http://dx.doi.org/10.12775/szhf.2020.006

\title{
Gerhard Preyer
}

Goethe University Frankfurt, Germany

E-MAIL: PREYER@EM.UNI-FRANKFURT.DE

ORCID: 0000-0002-1410-6864

\section{Concepts of Consciousness and Representation. Merits and Critiques of Higher and Same Order Monitoring Accounts in the Theories of the Mental}

\begin{abstract}
All possible consciousness as reality of the subject supposes an immediate consciousness within the subject and the object is one and the same. Without that consciousness is not intelligible in general. Johann Gottlieb Fichte $(1971,528)^{*}$
\end{abstract}

Every positional consciousness of an object is at the same time a non-positional consciousness of itself. Jean-Paul Sartre $(1956,13)$

Being an individual subject requires phenomenal consciousness. Tyler Burge $(2007,395)$

* Fichte: English translation of: "Alles mögliche Bewusstseyn, als Objectives eines Subjects, setzt ein unmittelbares Bewusstseyn, in welchem Subjectives und Objectives schlechthin Eines seyen, voraus; ausserdem ist ein Bewusstsein schlechthin unbegreiflich". 


\section{Introduction}

1. Turn to mental representation. Representationalism in the theory of the mental means that consciousness is always consciousness of something as intentionality which may be inexistent (Brentano). But, unlike Brentano, these theories of mental representation are physicalistic accounts. This implies, for example, the problem of false representations, and the problem of the content of the concepts of phenomenal properties, because propositional representations require concepts. But, in contrast, phenomenal/sensory representations are not propositional.

Since the 1990s, Harman's concept of representations and his critique on the invert spectrum has particular relevance. (Harman 1990a, 31-52, $1990 \mathrm{~b}$, 1-17, 1995, 2-17, Shoemaker 1995, 57-66) Harman's and Tye are externalized epistemologists: "you have no conscious access in the qualities of your experience by which it represents the redness of the tomato. You are aware (only) of the redness of the tomato." (Harman 1990 b, 8) This means that properties are not perceptible. They are perceptible properties of physical objects as representations of surface properties of an intentional direction of entities and, therefore, no intern properties of consciousness. This may be the reason because these authors are not hard core functionalists and modify functionalism and the mental as an "organ of representation" supplements by introspection epistemologically, for example, Goldman, Lycan und Kriegel. This is independent from their different accounts.

Shoemaker (1994, 314, 2000a, 247-273, 2000b, 465-468) argues that the introspection of sensory states has an intentional (representational) feature. This may be similar to Harman's account. Frank's argument, for example, is correct about that the "hard core externalists" enforces the phenomenal consciousness in the environment. The problem reference is that this is just a "petition principii" because the externalists, for example, Dretske and Tye, they infer from the "consciousness of __ to the "consciousness that ". The reason is rather simple, because we cannot take into consideration something that has not yet been conscious, for example, by a "displaced perception"/"secondary seeing" as an inward looking third-person point of view (Frank 2012, 17-18). 
2. Accounts. Since the 1990s, the problem situation (Popper 1972) has been a hybrid one. (Preyer 2015, 7-27, 2019, 186-224). There are accounts to analyse the phenomenal consciousness in the framework of functionalistic materialism (Lycan: phenomenal externalism), a turn to self-representationalism and a re-analysis of intentionality as phenomenal intentionality (Horgan, Horgan and Nichols, Kriegel, Williford, Zahavi), a reinterpretation of the analytic theory of self-consciousness recalling Sartre's enduring insight (Frank 2015, 2015, 53-94, Frank, Preyer 2020), and a new sequence of an exchange between American and European philosophers as well (Miguens, Preyer 2013).

In contemporary philosophy of the mental, we recognize debates on the existence and feature of different types of phenomenal consciousness, Iknowledge, thought, and posit them in the so-called stream of consciousness. The research program is a grosso modo constructing an unified framework of the core conditions and concepts for analysing phenomenal consciousness associated with thought and action. Firstly and secondly, the features of consciousness and the meaning of representation are distinguished with a systematic intent. Thirdly, the turn to the Same Order Monitoring Theory (self-representationalism) is sketched as a variation of the Higher Order Monitoring Theory in particular of Uriah Kriegel, its merits, and a critique of his introduction of representation as the "core necessary condition" of mental states.

The critique of the concept of representation as a basic concept of mental states and of self-representationalism is instructive about the re-systematization of the basic concepts of the philosophy of the mental and cognitive science because mental states are not an "organ of representation" as an introspection by self-monitoring on different level of the layered self-awareness. The conclusion gives some hint on an alternative account of the philosophy of the mental. It is the claim to show that the concept of representation as an intentional relationship is not the basic feature of mental states and the phenomenal consciousness. 


\section{Consciousness and the Meaning of Representation}

\subsection{Concepts of Consciousness and Its Features}

When we analyse the relationship between consciousness and the mental representation, it is useful to distinguish between different meanings of consciousness firstly. It is not disputed that mental representations are conscious mental states. But how do we qualify these states? This leads to the problem reference that the self-representation of conscious mental state is a misleading notion. Within literature, a distinction is made between the following concepts of consciousness (Lycan 2001, 2).

1. Consciousness ${ }^{1}\left(\mathrm{C}^{1}\right)$ as conscious awareness of one's own mental states and "conscious states" as states whose subject is aware of being in them.

2. Consciousness ${ }^{2}\left(\mathrm{C}^{2}\right)$ as introspection and one's privileged access to the internal character of one's experience itself, for example, "I am aware that I feel that I am in a good mood". Introspection is an attentional and intentional focused consciousness on the own mental states.

Lycan emphasizes that "1." and "2." are higher-order representation theories. They are to distinguish between an inner-sense and higher-orderperception/-thought proposals (Lycan 2001, 2).

3. Consciousness ${ }^{3}\left(\mathrm{C}^{3}\right)$ as being in a sensory state having a different qualitative/phenomenal property, for example, visual experience of colour or timbre of the heart sound.

4. Consciousness ${ }^{4}\left(\mathrm{C}^{4}\right)$ as "what it is like" for the subject to be in a particular mental state as the experience of a phenomenal narrow property like in $\left(\mathrm{C}^{3}\right)$. Block, for example, did not distinguish between phenomenal consciousness of $\left(C^{4}\right)$ and $\left(C^{3}\right)$ (Carruthers 2000). "What it is like" means the qualitative property itself and is not a higher order presented property (Dretske, Tye, Block 1995, 227-247, Dretske 1995, Tye 1995, Lycan 2001, 2). One problem 
reference is that Block's distinction is to correct that we can have qualitative properties even if we have no access to them. ${ }^{1}$

Analysing $\left(\mathrm{C}^{3}\right)$ and $\left(\mathrm{C}^{4}\right)$ the main question is whether the phenomenal property is a narrow or a wide content. This is the breaking point between internalism and externalism in the philosophy of the mental because externalism does not accept phenomenal entities, such as for example, quale as sense dates and phenomenal individuals (Russell, C. I. Lewis). Block's qualia are not intentional qualia (Block: fallacy of intentionalizing qualia. Block 1990, 53-79).

5. Consciousness ${ }^{5}\left(\mathrm{C}^{5}\right)$ as self-consciousness and perspective centred self. The expression "self-consciousness" is, systematically, a bit misleading because it can mean two things: an anonymous consciousness and referring to I myself. $^{2}$ The problem reference is to place self-consciousness as an elementary self-reference which is conscious as such and bring it together with the de se constraint as indexical self-reference. Some philosophers, for example, Lycan, van Gulick, Dennett, and Flanagan argue that self-consciousness is a virtual entity and no real component of experience. This is a variation of the $\mathrm{Hu}-$ meian account.

Distinguishing the primary (pre-reflective, primitive, for-me-ness feature) consciousness (self-consciousness) from I-knowledge as a conceptual knowledge, we obtain a fruitful framework for analysing the differentiation of mental states. The non-conceptual consciousness does not represent anything (Frank 2015, 17-18). The primitive self-reference as a non-conceptual consciousness is not mediated by an external third person attitude to I myself.

The main questions are following:

Is consciousness an "on/off affair" (Searle), is it empty_-going back to Plato's Theaitetos-(Sartre), or does it come in grades (Lycan and others)? ${ }^{3}$

${ }^{1}$ On critique of Block's contravalence between the phenomenal and the access consciousness: Burge 2007, 383-391, 392-419.

2 On the different meanings of self-consciousness: Frank 2015, 14-18, on a critiques on Hegel's concept of self-consciousness: 301-306.

3 See about with reference to McGinn, Searle, Rey, and White: Lycan 1996, 39-40. 
Is consciousness intentional (representational) as directed to something basically or is there something like a non-objective/non-conceptual consciousness?

What is the unity of consciousness (Brentano) and is there anything like an "inner awareness" (introspection)?

Are the five issues of consciousness connected with the concept of mental representation as an intentional relationship?

It is to mention that the concept of consciousness is also relevant for describing the relationship between conscious and unconscious mental states. This is also one of the problems within the ongoing controversy of the philosophy of the mental, for example, Dretske, Lycan, Searle, and many neurophysiologists.

\subsection{Meaning of Mental Representation}

1. Readings of the meaning of "representations". In the philosophy of the mental, there is a terminological problem concerning the readings of "representation" (Vorstellung, vorsichstellen: put before yourselves), which is to mention, because mental representations are connected with the conscious mental state trivially. Representation is the key-concept of philosophy since the 17th century. According to Locke's view, for example, "consciousness is the perception of what passes in a man's own mind" (Locke 1975, 138). "Ideas of reflection" require "attention". The modern epistemology has analysed "representation" by an inner awareness as a consciousness of/about something which is present by reflection (Locke).

Readings of the meaning of "representation" are following:

1. representation ${ }^{1}\left(\mathrm{R}^{1}\right)$ as "representation of something" (intentionality as representation, $x$ represents that ...) which has conditions of satisfaction $\left(\mathrm{R}^{4}\right)$,

2. representation ${ }^{2}\left(\mathrm{R}^{2}\right)$ as "conscious of/about", that is, a conscious quality which is conscious or not, for example, I am not conscious of the hair colour of my uncle-it is obvious that I can recall "the hair colour of my uncle" only if I was present of his "hair colour" in the past-, 
3. representation ${ }^{3}\left(\mathrm{R}^{3}\right)$ as "to stand for someone/something" (as representative), for example, deputy of a parliament or a symbol of a national flag ${ }^{4}$, and

4. representation ${ }^{4}\left(\mathrm{R}^{4}\right)$ as "representations" of conditions of satisfaction. According to Searle's view, for example, intentional mental states are a representation of conditions of satisfaction, and intentionality is a representation of the word-world directions of fit..$^{5}$ It is a property of the mind, thereby, the relation between the mind and the world is fixed. But Searle accepts the anonymous field of the subjective consciousness.

5. We recognize, along the four readings of "representation", a consequential problem of the concept of representation (Representation-consequential problem, $R^{5}$ ), because representation of something presupposes that the represented is already present. It is to emphasize that representation is a relation. This cannot achieve representation and introspection themselves as an object-directed attitude. ${ }^{6}$

2. Main questions. Mental representations connect the four features. The question is "How are related internal representations to the world. That is the so-called fitting problem?". One main difficulty is the assumption that there is a resemblance between representation and the external things, for example, the sense data represent extern objects. This concept of mental representation is not intelligible at all, because the things and events are not accessible and invisible. ${ }^{7}$ On the other hand, the self-presenting feature of consciousness is not to analyse by "representation of something" $\left(\mathrm{R}^{1}\right)$, "conscious of/about" $\left(\mathrm{R}^{2}\right)$, and "to stand for someone/something" $\left(\mathrm{R}^{3}\right)$. Representations as "conditions of satisfaction" $\left(\mathrm{R}^{4}\right)$ lead to the problem of the distinction of conditions of satisfaction by modes of the adequate and inadequate evidence of mental

${ }^{4}$ On $\mathrm{R}^{1-3}$ and a critique on the concept of representation as a non-sensory view: Tugendhat 1990, 86-87, Waldenfeld1999, 119-124.

5 Searle 1983. On a resystematization of Searle's theory of illocutionary acts: Ludwig 2003, 133-181, on the "fulfilment-conditional approach": Lepore, Ludwig 2007, 276-282.

6 On critiques of the "as-structure" (Castañeda: "ONEself refers to (thinks of) ONEselfqua oneSELF"), which has a relevance in principle as an argument against the concept of intentional representation and introspections: Frank 2012, 191-260.

7 On critique: Searle 1983, 59-60. On a comparable argument against Locke about we do not have an perception of state-of-affairs in the extern world, but of mental state-of-affairs which are caused from the external world: von Kutschera 2006, 51-55. 
states in the internal-external relationship between consciousness and environment. ${ }^{8}$ The adequate evidence is the primary (pre-reflective, primitive) consciousness $\left(\mathrm{C}^{5}\right)$ in the relationship of the "consciousness-consciousness of __." One of the main problems is to place the pre-reflective primitive feature of consciousness in the framework analysing mental states which are not conscious by reflection or representation.

\section{Self-Representationalism}

\subsection{Higher Order Monitoring Theory}

1. State consciousness. According to Harman, Dretske, and Tye, tokens play a role within the concept of representation. For them, representations are no inner properties of consciousness. Representations are surface properties, that is, representational states are nothing more than representational features. ${ }^{9}$ From Block, Burge, Kriegel, and Shoemaker's account is this account to extensive because the for-me-ness feature is not caused by the environment. The problem reference is the distinction between "being in a sensory state" and having a distinctive qualitative/phenomenal property $\left(\mathrm{C}^{3}\right)$ and as "what it is like" for the subject to be in a particular mental state $\mathrm{C}^{4}$ ) as an intrinsic quality and its "immediate or mediated representation" $\left(\mathrm{R}^{5}\right)$ which has its own "conditions of satisfaction" $\left(\mathrm{R}^{3}\right)$ as self-represented mental states.

The Higher Order Monitoring Theory, for example, (Rosenthal (2005), van Gulick 2004, 11-39), and Gennaro (2016, 17-18) argues that consciousness is the state consciousness, i.e., "we are conscious of ourselves as being in various mental states" and "the best explanation of all these things is that we are

8 The distinction goes back to Husserl. But it is not followed him making the distinction between internal and external perception epistemologically.

9 Lycan 2006 makes the useful distinction between a pure (Lloyd, Thau), a strong (Dretske, Tye, Lycan), and a weak representationalism in contemporary philosophy of mind. The first means representation is a token making qualia, the second means representation is a kind suffices for a qualia explaining by functionalism and materialism, and the third means representation qualitative states having representational content only. 
conscious of our mental states by having HOT's (=Higher Order Thought) that describe the states in those ways". (2005, 17-18)

(HOT) Necessarily $y^{*}$ for any mental state $x$ and experiential character $\mathrm{E}$, there is a property $\mathrm{F}$; such that $\mathrm{x}$ has $\mathrm{E}$ iff there is a suitable mental state $\mathrm{y}$, such that $\mathrm{y}$ represents $\mathrm{x}$ to be $\mathrm{F}$. (Kriegel 2011, 85)

2. Non-conscious mental states. Rosenthal applies the transitivity condition to all mental states, that is, transitive consciousness is a matter of being conscious of some mental states. Therefore, conscious mental states imply mental states of higher order. Every mental state $\mathrm{M}$ is conscious by a mental state of higher order $\mathrm{M}^{\prime}$ ' (consciousness $\left(\mathrm{C}^{1}\right)$ as "conscious awareness (thought) of one's own mental states") by representation $\left(\mathrm{R}^{1}\right)$ as "representation of something". The "conditions of satisfaction" $\left(\mathrm{R}^{4}\right)$ are layered without any end. The both mental states, $\mathrm{M}$ and $\mathrm{M}$, are two numeric and generic distinguished acts. It is not assumed that every mental state requires a conscious higher order state, but non-conscious mental states of higher order are to transfer to conscious mental states. The claim is to cut thereby the infinite regress with non-conscious mental states. Fichte, Brentano, Sartre, Henrich, and Frank recalled this tradition and recognized this problem reference. It is often forgotten that Sartre has this insight, and it is worthwhile to quote him because he gives a regress-free argument:

Either we stop at any one term of the series-the known, the knower known, the knower known by the knower etc. In this case the totality of the phenomenon falls into the unknown; that is, we always bump up against a non-conscious reflection and a final term. Or else we affirm the necessity of an infinite regress (idea ideae ideae, etc.), which is absurd ... Are we oblige after all to introduce the law of this [knower-known] dyad into consciousness? Consciousness of self is not dual. If we wish to avoid an infinite regress, there must be an immediate, non-cognitive relation of the self to itself. (Sartre 1956, 12)

HOT is to redescribe by $M$ is conscious by a "representation of something" $\left(\mathrm{R}^{1}\right)$, thereby the state is conscious by itself by "conscious of/about" $\left(\mathrm{R}^{2}\right)$ which stands as a numeric and generic act for conscious states as its own "condition of satisfaction" $\left(\mathrm{R}^{4}\right)$. This condition of satisfaction $\left(\mathrm{R}^{4}\right)$ is itself an unconscious 
condition. Every further conscious state on a higher level is a relationship of a self-application of the self-consciousness $\left(\mathrm{R}^{5}\right)$. Due to this analysis, we realize a regress in being in a conscious mental states because every conscious mental state is conscious by a "representation of something" $\left(\mathrm{R}^{1}\right)$ which is at the same time a "representation as conscious of/about (a quality)" $\left(\mathrm{R}^{2}\right)$.

But Levine, for example, argues that this is a mysterious relationship because having one unconscious mental state represents oneself as being in another unconscious state one comes thereby to be in a conscious state. How does it work that an unconscious mental state changes an unconscious state into a conscious one? (Levine 2016, 37)

\subsection{Same Order Monitoring Theory}

1. Claim of the account. Kriegel introduces the Same Order Monitoring Theory as a critique of the Higher Order Monitoring Theory. But he claims to transfer the Higher Order Monitoring Theory in a particular version of self-representationalism as a Same Order Monitoring Theory (Kriegel 2011, 94-100, Preyer 2014). He distinguishes the description of the general features of the phenomenal consciousness and its explanation as a systematization of its constitution. The claim is to answer the question whereby a phenomenal consciousness is a conscious one because the phenomenal consciousness has a qualitative character and a subjective feature. ${ }^{10}$ His claim is to connect the consciousnessas "conscious awareness of one's own mental states" $\left(\mathrm{C}^{1}\right)$, "consciousnessas being in a sensory state" having a distinctive qualitative/phenomenal property" $\left(\mathrm{C}^{3}\right)$ and consciousness as "what it is like for the subject to be in a particular mental state as the experience of a phenomenal property" $\left(\mathrm{C}^{4}\right)$ with the immediate representation (self-representation/

10 Kriegel 2009. His critiques on Rosenthal is 1 . Someone can be in a transitive conscious state of __ without in a intransitive conscious state. 2. Therefore, mental states are to characterize as hybrid or even as contradictorial. When I am in a conscious state then I am at the same time conscious about my-self. This is an intransitive state. 3 . It is to conclude that the transitive, intransitive and state consciousness is dependent on an intransitive consciousness. 20, 26-32, 118-120, Kriegel 2011 2011, 83-94, on "higher order tracking theory of experiential intentionality”, 94-100. On a review of Kriegel: Brogaard 2010. 
self-consciousness, $\mathrm{R}^{5}$ ) and consciousness ${ }^{2}$ as "introspection and one's privileged access" $\left(\mathrm{C}^{2}\right)$ which is both immediate and attentional.

2. Self-representation. Every directed representation is built in self-representation $\left(R^{5}\right)$. There are no two items between the two $M$ : $M$ and $M^{\prime}$ ', but $M=M^{\prime} . M=$ class of mental states which are not conscious necessarily, $M^{\prime}$ ' (consciousness $\left(\mathrm{C}^{1}\right)$ as "conscious awareness of one's own mental states") $=$ type of self-representation ("self-representation/self-consciousness", $\mathrm{R}^{5}$ ), that is, a conscious mental state of $\mathrm{M}$. Therefore, self-representationalism means:

(SR) Necessarily*, for any mental state $x$ and experiential character E, there is a property $\mathrm{F}$, such that $x$ has $\mathrm{E}$ if $x$ suitable represents itself to be $\mathrm{F}$ (Kriegel 2011, 85).

The consciousness of a mental state is self-evident. There is a generic identity between the two mental states M-M', that is, "[T]he representing and represented conscious states are one and the same". (Horgan, Kriegel 2006, 132, on a critique on both views: Levine 2006, 173-197) $\mathrm{M}$ is not conscious by a reflection because self-representation is built in $\mathrm{M}$. Representation is the "core necessary condition":

Thus, whatever else a conscious state may represent, it always also represents itself, and it is in virtue a representing itself that it is a conscious state (2009, 13-14).

Kriegel's insight is that self-representation is not to analyse by the representation $\left(\mathrm{R}^{1}\right)$ as "representation of something" (intentionality as representation), the representation $\left(\mathrm{R}^{2}\right)$ as "conscious of/about", and representation $\left(\mathrm{R}^{3}\right)$ as "to stand for someone/something" because every mental state is conscious as such as a "self-representation". It is a representation ${ }^{5}$ which has its own "conditions of satisfaction" $\left(\mathrm{R}^{4}\right)$. The ubiquity of self-awareness thesis (Kapi$\tan )$ means that phenomenal consciousness goes along with self-representation, and the dependent condition is that self-representation is a necessary condition having a phenomenal consciousness (Kapitan 1999, 17-44, Lang 2019). Our consciousness of mental states is self-evident. 
Kriegel distinguishes the primary and the secondary consciousness (reflection). The Higher Order and Same Order Theories vary thereby in that the "primary consciousness" $\left(\mathrm{C}^{5}\right)$ is a border-presentation which is centred in the focus of attention (shift-of-attention view, Kriegel, Horgan, Williford). Life experience and mental acts are conscious by the co-representation of their representational content. Therefore, Kriegel introduces the concept of introspection as an attention and an intentional focused consciousness of our own mental states epistemically. He distinguishes consciousness as "conscious awareness of one's own mental states" $\left(\mathrm{C}^{1}\right)$, consciousness as "conscious awareness of one's own mental states" $\left(\mathrm{C}^{2}\right)$, consciousness "being in a sensory state", having a distinctive qualitative/phenomenal property $\left(\mathrm{C}^{3}\right)$, and consciousness as "what it is like" for the subject $\left(\mathrm{C}^{4}\right)$. Subjective consciousness "what it is like" $\left(\mathrm{C}^{4}\right)$ unifies conscious states. It is the origin of intentionality itself. This is recalling of Brentano's spring of intentionality. Therefore, self-representationalists are called neo-Brentanoists.

\subsection{Subjective Consciousness}

1. Two accounts. Phenomenal conscious properties are experiential properties of sensations, feelings, perceptions, wants, emotions, and also thoughts. They are states of what is it like to have it as a subjective consciousness.

Within a slightly simplified picture, we distinguish between the two accounts regarding to the analysis of the structure of consciousness:

1. Consciousness is determined by phenomenal features. These are the so-called "separatists" resp. "dualists" who argue for a two component theory. Prominent representatives are, for example, Nagel, Block, Jacobson, and Levine. Their account is to characterize thereby that no physical information can explain subjective experiences. Qualia, as a narrow content of introspective qualitative phenomenal properties of sensations, are no physical state.

2. The unified feature of consciousness is its representational power. These accounts re-interpret Brentano's theses of intentionality of consciousness.

There are two versions of the last: 
(a) Consciousness is an organ of representation (Lycan, Tye), that is, mental states-also sensations and moods-are intentional in general. The authors defend Brentano's thesis of intentionality.

(b) The meta-mental (higher-order) representation account (Rosenthal, Dennett, von Eckhardt). Dretske and Tye mean with "what it's like" a qualitative property and the "present higher-order property of this property").

There are also mixed versions of both accounts which re-interpret the concept of representation with the basic concept of higher-order-representation, for example, Lycan and Kriegel.

3. Horgan, Horgan and Nichols, Kriegel, and Williford, for example, make a turn to the self-representationalism since the early 2000s, which takes effect up to the present and has actualized the problem reference of the phenomenal consciousness. (Horgan, Kriegel, 2007, 123-144, Kriegel 2006, 143-170, Williford 2006 111-142. The analysis and critiques of the higher order and same order account by German philosophers needs to be mentioned: Frank 2012, 2012, 369-397, Frank, Preyer 2020, Lang 2018).

2. Non-egological consciousness. The phenomenal consciousness "what it is like" $\left(\mathrm{C}^{4}\right)$ is immediate. It is, for example, a pain consciousness, a consciousness, which is immediately (pre-reflective) present as such ("what it is like" $\left(\mathrm{C}^{4}\right)$ and the "primary consciousness" $\left(\mathrm{C}^{5}\right)$. Kriegel distinguishes between the qualitative consciousness ("being in a sensory state" having a distinctive qualitative/phenomenal property, $\mathrm{C}^{3}$ ) and the for-me-ness feature (Ned Block, Tyler Burge: non-conceptual egocentric sensitivity) as the whole phenomenon of phenomenal consciousness. He calls the last subjective consciousness without egological information. The distinction is useful. The qualitative consciousness represents properties of perceived and experienced entities.

The representation as properties of entities determines the phenomenal consciousness as such and the type of consciousness which is represented, for example, as a conscious colour or a feel experience. By the subjective consciousness, the quality state has the character of consciousness only. "For me-ness" does not mean "with me". The "for me" locution is a conceptualization "of his or her perspective as mine" (Kapitan 2016, 61-62). Within the 
subjective consciousness, Kriegel does not distinguish between the phenomenal and the form of conceptualized me-ness feature, that is, between "being in a sensory state", having a distinctive qualitative/phenomenal property $\left(\mathrm{C}^{3}\right)$ as the content of phenomenal consciousness, and the immediate (pre-reflective) present as such of "what it is like" $\left(\mathrm{C}^{4}\right)$. For him, the qualitative content is determined by the environment (Kriegel 2009, Capt. 1, Frank 2012, 386). Thereby, he goes along with the externalism of the individuation of the phenomenal content (Tye, Dretske, and Harman).

The problem reference is, whatever may be: the quality of phenomenal consciousness is anonymous as an immediate consciousness, which is not to express in the first-person expression as "mineness" and is not identical with the structure of the event in the environment, for example, molecular movements or neurologically described events. Such identity statements are contingent. It is to mention that mineness is no Jemeinigkeit (Heidegger). The question is following: are states of consciousness and states of the brain to map within the self-consciousness (question of cognitive closure) (Kripke 1971, 162-164)?

\section{Conclusion}

\subsection{Two-Vehicle-One-States View and Introspection}

1. Main questions. The merit of self-representationalism shows at the same time its problem in principle, because the structure of consciousness is determined by the conscious state representing itself, that is, by the ubiquity and transparency of self-awareness. This means that an immediate as an unmediated consciousness is ever-present in all conscious mental states.

The main problems are

How does the concept of representation go along with the Same-Order Monitoring Theory? How is the privileged access to our mental states to characterize as a relationship between the privileged self-reference and the mental (phenomenal) properties because this is not an external relation? If people 
ascribe themselves phenomenal states, then we ask: what is the representation of these states?

2. Shift of attention. The Same Order Account is a one place theory of consciousness, but the concept of representation turns to a two-vehicle-one-states view (Levine 2009, 1-11: shift of attention). The Higher Order Monitoring Theory and the Same Order Monitoring Theory are not different in principle because it is assumed as basic concept that the higher order act refers to a lower act or the relation is one between an act and the act itself. Levin has recognized this problem correctly:

On both views, the consciousness, or awareness, is constituted by the representation of a target state (Levine 2006, 175).

When we assume a shift of attention, then the primary consciousness is not an unmediated consciousness. It is a subject of attention only (Frank 2012, with reference to Brentano's critiques, 387). It is assumed that phenomenally lived experiences are proto/rudimentary-concept (Horgan, Kriegel). Just this was, for example, the answer to some "New Wave" type identity philosophers toward the anti-materialists, for example, Hill, and van Gulick. Call that "gateway in concepts"."1

When we qualify the secondary (internal) consciousness as an in-attentive performance of non-explicit conceptual, reflective, or attentive self-knowledge, then it is the claim to explain self-consciousness by a change from an inattentive to an attentive consciousness.

But what does this mean?

This classification is circular because the higher-order notions are explained by proto/rudimentary concepts which are assumed to systemize the mentioned change.

11 Kim 2005 is informative on an overview and the consequential problems turning to the "New Wave". He refers to Hill, McLaughlin, Block, and Stalnaker. It is to distinguish the Hill-McLaughlin, and the Block-Stalnaker argument, 131-146, on both 146-148. It is not the subject of the article whether the arguments by Nagel, Jackson, and Chalmers are reasoned well enough, see, for example, Lycan 2003, 130-147. The concept of explanatory gab goes back to Levine 1983, 354-361. 
The Higher and Same Order Account also run out in a regress. This is emphasized by Frank $(2015,144-145)$. When mental states are conscious by iteration, only then we are not conscious about our-self on every level directly. Every level starts from its own "level". We would be conscious on the second level about our mental state on the first level and about the mental state on the second level firstly on the third level. But, on the third level, we do not have any evidence about whether we are conscious of our-self on the second level. We would be an entity without consciousness. (Castañeda: reference to "Oneself qua oneSELF", Chisholm: he, him-self locution, Lewis: de se attribution; this self-reference is called "de se"-constraint generally). Therefore, higher-order iteration does not show that a subject is in a conscious mental state. $^{12}$

\section{Introspection (perception). Amstrong argues}

Introspective consciousness $\ldots$ is a perception-like awareness of current states and activity in our mind. The current activities will include sense-perception: which latter is the awareness of current states and activities of our environment and our body. (Amstrong 1980, 65-66, Lycan, 1997: internal attention mechanisms directed upon lower-order psychological states and events as well as with a little bit teleology, 755-773)

For Kriegel and Zahavi (2015, 41-42), introspection is an attentional, intentional and focused consciousness of the own mental states $\left(\mathrm{C}^{2}\right)$. Goldman, for example, argues that attention is important for introspection, and there is a parallel of introspection and external perception (Kriegel, Zahavi). Therefore, it is assumed that introspection is directed to conscious states, and is a self-objectifying awareness of conscious mental states. Introspection $\left(\mathrm{C}^{2}\right)$ means perception. It is the key to connect consciousness $\left(\mathrm{C}^{3}\right)$ as "being in a sensory state" having a distinctive qualitative/phenomenal property, consciousness $\left(\mathrm{C}^{4}\right)$ as "what it is like" for the subject to be in a particular mental state as the experience of a phenomenal property and "self-consciousness" $\left(\mathrm{C}^{5}\right)$ with representation as "conscious of/about" $\left(\mathrm{R}^{2}\right)$ and the representation to stand for someone/something" $\left(\mathrm{R}^{3}\right)$. Expressed or unverbalized, it is an

\footnotetext{
12 This could be an argument against the naturalized epistemology.
} 
objectification of conscious mental states. However, this leads to an infinite regress.

In principle, the critique on the concept of introspection is that it is not possible to take myself to the point of view of an external observer. (Tye: displaced perception/secondary seeing ${ }^{13}$, Shoemaker (1984, 1996 205, Frank 2012, 329-368): critiques on the "inward glance"-model). Every observation is directed to an object. But consciousness is not an object of itself and has no grades (Brentano, Sartre).

4. Another account. Frank, Zahavi $(1999,33)$ and Shoemaker emphasize, from different theoretical point of views, that we need another approach in the philosophy of the mental. We have to give up the concept of representation as basic concept of mental states. We require an account which does not systemize the acquaintance of $\mathrm{M}^{*}$-Consciousness $\left(\mathrm{C}^{1}\right)$ as "conscious awareness of one's own mental states"-with any $\mathrm{M}$ by the reflective-pronominal use of language and a relation, but with the jointless unit of the mental and its differentiation. Therefore, it is argued that consciousness is constituted by the pre-reflective consciousness which is unmediated, irreflective, non-objectifying, and non-conceptual, that is, by a reinterpretation of self-consciousness $\left(\mathrm{C}^{5}\right)$. The basic relation of systematization is not representation, attention, or reflection. Therefore, it is to conclude that there is no "hegemony of representation" as basic concept of mental states like, for example, Lycan $(1997,755)$ argues.

But it is to mention that the members of the group of self-representationalists go in different directions in the meantime; for example, Horgan, Horgan and Nichols make a stronger turn against materialism, Kriegel claims to match the intentional phenomenology of the mental with naturalized epistemology and an unified framework of types of phenomenal experience, Williford has modified his position and accepts a primitive simplicity of the acquaintance of mental states, but he has not given up the projection model (Williford, Rudrauf, Landini 2016, 321-353, Williford 2006 1-8, Lang 2018, 2019).

13 Tye argues for an intentional structure of phenomenal consciousness and its external individuation which is to correct. 


\subsection{Non-Distinguish Theses and the Immediate Consciousness}

1. Phenomenal states. We usually have both, the state consciousness and the I-consciousness. But they are related in its foundation asymmetrically. ${ }^{14}$ State consciousness is a stream of lived experience or consciousness of flowing lived experience as an anonymous consciousness. Horgan and Nichols called that "phenomenal subjectivity". Horgan Nichols (2016, 146-147), Horgan (2004, 329-350). ${ }^{15}$ Levine (2016, 342-361), Kapitan (2016 49-65), and Eshleman (2016, 166-207), for example, go in the same direction theoretically. It is remarkable that they agree with the Henrich-Frank tradition on:

Instead, such experiential self-presence is an immediate-i.e. unmediated-involvement of the self in consciousness, as opposed to mediated involvement via the conscious representation of self. (Horgan, Nichols 2016, 146-147) ${ }^{16}$

In the relationship "consciousness-consciousness of __" cannot be the consciousness-consciousness as a conscious awareness of one's own mental states $\left(\mathrm{C}^{1}\right)$ as a representation of something $\left(\mathrm{R}^{1}\right)$ and a conscious of/about $\left(\mathrm{R}^{2}\right)$. The phenomenal states themselves as a consciousness $\left(\mathrm{C}^{4}\right)$ "what it is like" are not to distinguish from the phenomenon of these states in contrary to neuronal

14 We have conscious states in both cases (non-egological phenomenal consciousness and I-consciousness), but the subject is different. Self-reference to I my-self presupposes that I am familiar with my-self before I refer to I my-self (distinction between I-use and object-use of I-sentences (Shoemaker). This leads to the problem whether I-knowledge and its relation to the immediate consciousness is a performative act. But an I-utterance cannot be a performative act only, as Anscombe argues. Chisholm's argument is, for example, she has no analysis of direct attribution. The word "I" refers to as quasi-indication (Castañeda) of an ephemeral I-state. The utterance of the word "I" expresses a condition which is self-referential to the speaker it-self. The reference is direct and is not one by reflection. But this note about phenomenal states and I-consciousness is a hint only.

15 The Graham-Horgan-Tienson account of the secondary-quality content of perceptual experience is to distinguish from, for example, G. Strawson, Siewert, Loar, and Kriegel.

16 But the (in-)unmediated anonymous consciousness is also threatened by a circle, Frank 2012, on non-egological explanations of self-consciousness, 43-44, regarding to Chisholm, 133-134. The question is, for example, how a punctual self-reference act of consciousness goes along to a continuum of acts and the "conscious of itself" of monads is lingually expressed in a reflective mode of expression? A circle does not happen when we analyse the unity of consciousness, its intern transparency, and the articulation of its differentiation. 
states as extern objects of the mental. Therefore, we are conscious of phenomenal states immediately by their manifestations without any judgement, which is conceptual (Block 2003, 165-200).${ }^{17}$ It is to emphasize that this notion of pre-reflective consciousness of the "consciousness-consciousness" relationship does not hold true for body sensations of the consciousness $\left(\mathrm{C}^{3}\right)$ "being in a sensory state" only, but it also extends to desiring and thinking. ${ }^{18}$ But it is also to mention that I-consciousness as a feature of self-consciousness $\left(\mathrm{C}^{4}\right)$ is also conscious as such. Therefore, there is anything as a self-consciousness as self-perception. Conscious awareness of one's own mental states $\left(\mathrm{C}^{1}\right)$ as a representation of something $\left(\mathrm{R}^{1}\right)$ and a conscious of/about $\left(\mathrm{R}^{2}\right)$ is not the analysans of self-consciousness $\left(\mathrm{C}^{5}\right)$

The phenomenal consciousness is a transparent lived experience $(E)$. We do not classify this lived experience $(E)$. The immediate phenomenal consciousness is the pre-reflexive (non-conceptual) and non-relational self-consciousness, for example, the classification of the red things in the room has to distinguish between the classificatory frame like, for example, counting, locating, fixing time-points of things and events, and the self-presentation of the qualities as $\mathrm{C}^{4}$. Classes do not have a quality-the class is not red-but the for me-ness does not differ from the lived experience $(E)$. Body feelings as being in a sensory state $\left(\mathrm{C}^{3}\right)$ are conscious as such, and they are not to be reduced to neuronal events. All body events as a physical category are to be characterized thereby that they have no self-referential features. This is the argument for the dual component account in the philosophy of the mental.

2. For-me-ness. If mental states are conscious, then they are accompanied simultaneously by the immediate consciousness. It is an intrinsic property of (conscious) mental states which are conscious as such. Therefore, it is to conclude that one must distinguish between "having the property of consciousness" as "primary self-reference (direct self-attribution)" $\left(C^{5}\right)$, phenomenal

17 Therefore, Block's argument is instructive with a little reinterpretation: "one can be aware of what one is not attending to", 7. Henry 2004: His critique on Husserl's concept of intentionality is relevant because the elementary mode of appearing (lived experience) is not intentional as a consciousness of states.

${ }_{18}$ Gallagher, Zahavi 2015 are also on board going along with this foundation of mental 
property as a "for-me-ness feature" $\left(\mathrm{C}^{4}\right)$, and "having a sensory property" $\left(\mathrm{C}^{5}\right)$. The link between consciousness ${ }^{1-5}$ is not an intentional representation which is to be specified by representation as a condition of satisfaction $\left(\mathrm{R}^{4}\right)$ to the external environment.

With the immediate consciousness, we identify the features of all mental state types as conscious ones, if they do not have any resonance within the physical. The primary self-reference $\left(\mathrm{C}^{5}\right)$ is to be distinguished from the phenomenal consciousness as the what-it-is-likeness-feature $\left(\mathrm{C}^{4}\right)$, that is, the qualitative/subjective/phenomenal experience (what-it-is-like-ness), for example, pain, taste, or sadness $\left(\mathrm{C}^{4}\right)$. All the phenomenal properties are conscious as such. They stand for themselves as the for-me-ness of experience. We have phenomenal properties as a subjective consciousness only by the self-evidence of the immediate consciousness. Maybe we have unconscious mental states by phenomenal properties only. The critique on Freud's "unconsciousness" from Husserl, Sartre, the mysterious Lacan, MacIntyre, and Searle is well-known among many philosophers. It is not disputed that not all mental states are conscious as such. The problem is that Freud has not an adequate analysis of consciousness making clear the access to the unconsciousness.

The phenomenal consciousness is not primary to instantiate to the $I$-knowledge (self-knowledge). The for-me-ness is an anonymous conscious state. It is not an acquaintance with me as something. But there is a relationship between both, because the egocentric concept marks this view as a self-referential perspective $\left(\mathrm{C}^{5}\right)$ every I-speaker has, or I ascribed to I my-self. Phenomenal states are not a case of recognitional concepts as dispositions, which refer to from the first-person stance and are thereby selected physicalfunctional properties of the brain, and are at the same time as concepts independent from physical descriptions. Therefore, they are not self-directed recognitional concepts (Loar 2002, 295-311).

3. Priority of pre-reflective consciousness. It is to conclude: being conscious is a matter having a phenomenal and a non-conceptual consciousness. Therefore, it is obvious that phenomenal consciousness is prior to introspection, and it is not an introspection of qualia. A mental state is conscious by itself, if it goes along with a pre-reflective consciousness, that is, we have unmediated mental 
states. The unity of consciousness (Brentano) is that every mental state is the same conscious state. Having consciousness and having a mental state are to be distinguished from each other because mental states are constituted by consciousness as being conscious, and I am familiar with my mental states. We have different mental states, and every mental state is conscious self-referentially by itself as a conscious state. Therefore, the jointless unit of consciousness, that is, its ubiquity, is to be distinguished from the single mental states. We do not refer to the subjectivity of our lived experiences $(E)$ from an extern point of view and conscious about is not a reflective relation.

4. Outlook. It is to distinguish between the phenomenal consciousness and the first person indexical status of I-knowledge. The first is anonymous and the second is conceptual. Giving a hint of the architecture of the mental. The mental is structured thereby:

The distinction between the immediate consciousness as an access consciousness as an intuitive one and the phenomenal consciousness $\left(\mathrm{C}^{3}\right.$ and $\left.\mathrm{C}^{4}\right)$ on the one side, and (I-)self-knowledge $\left(\mathrm{C}^{5}\right)$, intentional states (propositional consciousness, $\mathrm{R}^{1}, \mathrm{R}^{2}$ ), the consciousness of time, and existence-consciousness on the other side is made because (I-) self-knowledge, intentional states (propositional consciousness), the consciousness of time, and existence-consciousness are not to be explained by the first both, because they are also conscious as such. ${ }^{19}$ Call that the "varieties of consciousness/subjectivity" (Frank, Kriegel). The existence-consciousness is introduced because there is no total self-transparency about our self and existence in the world. The structure of consciousness is to be analysed by the self-articulation of its own transparency and external relationship as a dual component theory. Consciousness is not derived from other instances and has its own complexity.

The answer to the question of the strength of immunity of self-reference of mental states is to be given through the analysis of the differentiation of the structure of immunity by the distinction between an adequate $\left(\mathrm{C}^{5}\right)$ and inadequate evidence $\left(\mathrm{R}^{1}, \mathrm{R}^{2}\right)$. The adequate evidence is self-fulfilled by itself and does not have intentional objects, but it does not exclud something like self-deception (Gallagher 2016, 245-272). Maybe this evidence is like under

19 On existence consciousness: Preyer 2016, 189-211. 
the influence of morphine. The inadequate evidence is the domain of cognition, that is, memory, belief, and error which have an intentional content. This evidence is incomplete because we recognise the extern reality by cross reference of indexicality only. The fulfilment condition of the inadequate goes beyond the adequate evidence. It could be an alternative to re-interpret Sartre's reflet-reflétan linking with the inadequate and the adequate evidence as another concept of representation as a reflex. We could compare this concept of representation with Frege's Sinn or Husserl's noёma (Burge: problem of content preservation). (Frank 2015, 168-172, Frank, Preyer 2020)

The questions of the theory of consciousness are not the explanatory gap, the knowledge argument, and the reduction of consciousness only, but how different features of consciousness are to be analysed with the basic concepts of mental states, of action, and of personality. Research is required to give up the ideological and programmatic occupations of materialism and functionalism which have dominated the philosophical interest in consciousness. In particular, consciousness is not to be defined by other terms. It is to conclude: we will understand the mental but not necessarily as a physical theory (Nagel), or we will understand the mental but not by a physical state only. ${ }^{20}$

\section{Bibliography}

Amstrong D. M. 1980. "What is Consciousness". In: The Nature of Mind and Other Essays, Ithaca, NY: Cornell University Press.

Block Ned. 1990. "Inverted Earth". In: Philosophical Perspectives 4: Action Theory and Philosophy of Mind. Ed. James E. Tomberlin. Atascadoro, CA.

Block Ned. 1995. "On a Confusion about a Function of Consciousness," Behavioural and Brain Sciences 18.

Block Ned. 2003. "Mental Paint". In: Reflections and Replies. Essays on Tyler Burge. Eds. Martin Hahn, Bjørn Ramberg. Cambridge, MA: MIT.

Burge Tyler. 2007. "Reflections on two kinds of consciousness". In: Foundation of Mind. Oxford: Oxford University Press.

Burge Tyler. 2007. “Two Kinds of Consciousness (1997)”. In: Foundation of Mind. Oxford: Oxford University Press.

20 On further research: ProtoSociology 2019. 
Burge Tyler. 2007. "Reflections on Two Kinds of Consciousness (2006)". In: Foundation of Mind. Oxford: Oxford University Press.

Brogaard Berit. 2010. "Subjective Consciousness Reduced?". Proto Sociology Review Philosophy. Access 18.03.2020. http://www.protosociology.de/reviews.html

Carruthers Peter. 2000. Phenomenal Consciousness. Cambridge: Cambridge University Press.

Dretske Fred. 1995. Natrualizing the Mind. Cambridge, MA: MIT Press.

Eshleman Matthew. 2016. "Sartre's Error Theory of Introspection". In: Sartre and Contemporary Philosophy of Mind. Eds. Sofia Miguens, Gerhard Preyer, Carla Bravo Morando. Abingdon: Routledge.

Fichte Johann G. 1971. "Versuch einer neuen Darstellung der Wissenschaftslehre (1897)". In: Fichtes Werke. Hrsg. Immanuel Hermann Fichte I, Zur theoretischen Philosophie I. Berlin: De Gruyter.

Frank Manfred (ed.). 1991. Selbstbewusstsein bei Fichte und Sartre. Frankfurt a. M./Berlin: Suhrkamp.

Frank Manfred. 2012. Ansichten der Subjektivität. Frankfurt a. M./Berlin: Suhrkamp. Frank Manfred. 2015. Präreflexives Bewusstsein. Vier Vorlesungen. Stuttgart: Reclam. Frank Manfred, Gerhard Preyer. 2020. "Prereflectivity and Contemporary Philosophy of Consciousness". In: Routledge Philosophy Minds: Sartre. Eds. Matthew Eshleman, Constance Mui, Christophe Perrin. Abingdon: Routledge.

Gallagher Shaun, Dan Zahavi. 2015. "Phenomenological Approach to Self-Consciousness". 3. In Stanford Encyclopedia of Philosophy. Access 18.03.2020. http:// plato.stanford.du/archives/spr2015/entries/self-consciouness-phenomenologi$\mathrm{cal} /$.

Gallagher Shaun. 2016. "First-Person Perspective and Immunity to Error Through Misidentification". In: Sartre and Contemporary Philosophy of Mind. Eds. Sofia Miguens, Gerhard Preyer, Carla Bravo Morando. Abingdon: Routledge.

Gennaro Rocco J. 2016. "The 'of' of intentionality and the 'of' of acquaintance". In: Pre-reflective Consciousnes. Sartre and Contemporary Philosophy of Mind. Eds. Sofia Miguens, Gerhard Preyer, Carla Bravo Morando. Abingdon: Routledge.

Goldman Alvin. 2006. Simulating Minds. The Philosophy, Psychology, and Neuroscience of Mindreading. Oxford: Oxford University Press.

Harman Gilbert. 1990. "The intrinsic Quality of Experience". In: Philosophical Perspectives. 4. Action, Theory and Philosophy of Mind. Ed. James Tomberlin. Atascadero: Ridgeview.

Harman Gilbert. 1990. "Explaining Objective Color in terms of Subjective Reactions". Philosophical Perception 7.

Harman Gilbert. 1995. "Explaining Objective Colors in Terms of Subjective Relations". Philosophical Issues, 7. Perception. 
Henry Michel. 1990. (second edition) English 2004 (second edition). L'essence de la manifestation. Paris: P.U.F. English Translation by G. Etzkorn: The Essence of Manifestation. The Hague: Martinus Nijhoff.

Herman Gilbert. 2000. "Phenomenal Character Revisited". Philosophy and Phenomenological Research IX (2).

Horgan Terry. 2004. "Phenomenal Intentionality and Secondary Qualities: The Quixotic Case of Color". In: Does Perception Have Content?. Ed. Berit Borgaard. Oxford: Oxford University Press.

Horgan Terry, Shaun Nichols. 2016. “The zero point and I". In: Pre-reflective Consciousness. Sartre and Contemporary Philosophy of Mind. Eds. Sofia Miguens, Gerhard Preyer, Carla Bravo Morando. Abingdon: Routledge.

Horgan Terry, Uriah Kriegel. 2006. "Phenomenal Epistemology: What is Consciousness that We May Know It so Well?". In: Self-Representational Approaches to Consciousness. Eds. Uriah Kriegel, Kenneth Williford. Cambridge, MA: MIT Press.

Kapitan Tomis. 1999. "The Ubiquity of Self-awareness". Grazer Philosophische Studien 57.

Kapitan Tomis. 2016. "Is Subjectivity First-personal, has emphasized that". In: Prereflective Consciousness. Sartre and Contemporary Philosophy of Mind. Eds. Sofia Miguens, Gerhard Preyer, Carla Bravo Morando. 61-62. Abingdon: Routledge.

Kim Jaegwon. 2005. Physicalism, or something near enough. Princeton: Princeton University Press.

Kriegel Uriah. 2009. Subjective Consciousness A Self-Representational Theory. Oxford: Oxford University Press.

Kriegel Uriah. 2011. Sources of Intentionality. Oxford: Oxford University Press.

Kriegel Uriah, Dan Zahavi. 2015. "For-me-ness: What it is and what it is not". In: Philosophy of Mind and Phenomenology: Conceptual and Empirical Approaches. Eds. Daniel O. Dahlstrom, Andreas Elipodorou, Walter Hopp. London: Routledge.

Kripke Saul A. 1971. "Identity and Necessity". In: Identity and Individuation. Ed. Milton K. Munitz. New York: New York University Press.

Lang Stefan. 2018. Phänomenales Bewusstsein und Selbstbewusstsein. Hamburg: Meiner.

Lang Stefan. 2019. Performatives Selbstbewusstsein. Paderborn: Mentis.

Lepore Ernest, Ludwig Kirk. 2007. Donald Davidson's Truth-Theory. Oxford: Oxford University Press.

Levine Joseph. 1983. "Materialism and Qualia: The Explanatory Gap". Pacific Philosophical Quarterly 64.

Levine Joseph. 2006. "Conscious Awareness and (Self-)Representation". In: Self-Representational Approaches to Consciousness. Eds. Uriah Kriegel, Kenneth Williford. Cambridge: MIT Press. 
Levine Joseph. 2009. "Review of Kriegel". Philosophical Review. University of Notre Dame.

Levine Joseph. 2016. “Quasi-Sartrean' Theory of Subjective Consciousness”. In: Pre-reflective Consciousness. Sartre and Contemporary Theory of Mind. Eds. Sofia Miguens, Gerhard Preyer, Carla Bravo Morando. Abingdon: Routledge.

Loar Brian. 2002. "Phenomenal States". In: Philosophy of Mind. Ed. David Chalmers, New York: Oxford University Press.

Locke John. 1975. An Essay Concerning Human Understanding (1690). Vol. 2, Oxford: Clarendon Press.

Ludwig Kirk. 2003. "The Truth about Mood". In: Concept of Meaning. Framing an Integrated Theory of Linguistic Behavior. Eds. Gerhard Preyer, Georg Peter, Maria Ulkan. Dordrecht: Kluwer.

Lycan William. 1996. Consciousness and Experience. Cambridge: MIT Press.

Lycan William. 1997. "Consciousness as Internal Monitoring". In: The Nature of Consciousness. Philosophical Debates. Eds. Ned Block, Owen Flanagan, Güven Güzeldere. Cambridge: MIT Press.

Lycan William. 2003. "VS. A New A Priorist Argument for Dualism". Philosophical Issues 13. Philosophy of Mind.

Lycan William. 2006. "Representational Theories of Consciousness (2001)". Substantive revision Oct 9, Stanford Encyclopedia of Philosophy. Access 18.03.2020. http://plato.stanford.edu/entries/consciousness-representation/

Miguens Sofia, Gerhard Preyer (eds.). 2013. Consciousness and Subjectivity. Berlin: De Gruyter.

Miguens Sofia, Gerhard Preyer, Carla Bravo Morando (eds). 2016. Pre-reflective Consciousness. Sartre and Contemporary Philosophy of Mind. Abingdon: Routledge.

Popper Karl. 1972. Objective Knowledge. Oxford: Clarendon.

Preyer Gerhard. 2015. "On contemporary philosophy of mind. From the 1950s years to the present". Ruch Filozoficzny 71 (4).

Preyer Gerhard. 2013. "The Problem of Subjectivity: On Dieter Henrich's Turn”. In: Consciousness and Subjectivity. Eds. Sofia Miguens, Gerhard Preyer. Berlin: De Gruyter.

Preyer Gerhard. 2014. "Besprechung Kriegel: The Sources of Intentionality". Zeitschrift für philosophische Forschung 68 (1). Access 18.03.2020. https://www.academia.edu/32152774/U_Kriegel_Sources_of_Intentionality_Review_GPreyer

Preyer Gerhard. 2019. "Zur gegenwärtigen Philosophie des Mentalen". In: Die Philosophie der neuesten Zeit, Bd. 7. Ed. Wolfgang Röd, Wilhelm K. Essler. Unter Mitarbeit von Christine Bratu, Gerhard Preyer und Julian Nida-Rümelin. München: Beck.

Senses of Self. Approaches to Pre-Reflective Self-Consciousness. 2019. Ed. Marc Borner, Manfred Frank, Kenneth Williford. ProtoSociology (36). 
Sartre Jean-Paul. 1956. Being and Nothingness. Trans. H. E. Barnes. New York: Philosophical Library.

Searle John. 1983. Intentionality. An Essay on the Philosophy of Mind. Cambridge: Cambridge University Press.

Shoemaker Sydney. 1984. Cause, and Mind. Philosophical Essays. Cambridge: MIT Press.

Shoemaker Sydney. 1994. "Introspection and 'Inner Sense". Philosophy and Phenomenological Research LIV.

Shoemaker Sydney. 1994. "Phenomenal Character”. Noûs 28.

Shoemaker Sydney. 1995. "Colors, Subjective Reactions, and Qualia”. Philosophical Issues. 7. Perception.

Shoemaker Sydney. 1996. The First Person Perspective and Other Essays. Cambridge: Cambridge University Press.

Shoemaker Sydney. 2000a. "Introspection and Phenomenal Character". Philosophical Topics 28.

Shoemaker Sydney. 2000b. "Phenomenal Character Revisited". Philosophy and Phenomenological Research IX.

Tugendhat Ernst. (1990 - second edition). Einführung in die Vorlesungen zur Einführung in die sprachanalytische Philosophie (1976). Frankfurt a. M./Berlin: Suhrkamp.

Tye Michael. 1995. The Problem of Consciousness. Cambridge, MA: MIT Press.

Van Gulick Robert. 2004. "Higher-Order Global States: An Alternative Higher-Order Model of Consciousness". In: Higher-Order Theories of Consciousness: An Anthology. Ed. Rocco J. Gennaro. Cambridge, MC: John Benjamins.

Von Kutschera Franz. 2006. Die Wege des Idealismus. Paderborn: Mentis.

Waldenfeld Bernhard. 1999. Vielstimmigkeit der Rede. Studien zur Phänomenologie des Fremden 4. Frankfurt a. M./Berlin: Suhrkamp.

Williford Kenneth. 2006. "The Self-Representational Structure of Consciousness". In: Self-Representational Approaches to Consciousness. Eds. Uriah Kriegel, Kenneth Williford. Cambridge, MA: MIT Press.

Williford Kenneth. 2006. "Zahavi versus Brentano: A Rejoinder". Psyche 12.

Williford Kenneth. 2006. Self-Representational Approaches to Consciousness. Cambridge, MA: MIT Press.

Williford Kenneth (with David Rudrauf and Gregory Landini). 2013. "The Paradoxes of Subjectivity and the projective Structure of Consciousness". In: Consciousness and Subjectivity. Eds. Sofia Miguens, Gerhard Preyer. Berlin: De Gruyter.

Zahavi Dan. 1999. Self-Awareness and Alterity. A Phenomenological Investigation. Evanston: Northwestern University Press. 


\begin{abstract}
Concepts of Consciousness and Representation. Merits and Critiques of Higher and Same Order Monitoring Accounts in the Theories of the Mental

The concept of representation has been renewed in the philosophy of the mental since the 1990s epistemically. But there are no unified accounts and different concepts of representation and consciousness as well. Therefore, differentiated analysis is desirable to give some clarifications of "consciousness" and "representation". In particular, the higher order monitoring and same order monitoring theories have their merits in the philosophy of the mental, but their basic concept of higher and same order mental states do not give an adequate account in the theory of the mental because the basic concept is not an intentional relationship of representation. Therefore, an outlook to an alternative turn is given as a tentative orientation.
\end{abstract}

Keywords: Philosophy (theory) of the mental, consciousness, mental representation, higher order monitoring and same order monitoring theory, prereflective consciousness, phenomenal consciousness. 